\title{
CONTEXTUAL EFFECTS ON ETHICAL SENSITIVITY AND PENALTY JUDGMENTS
}

\author{
The Turkish Case ${ }^{\star}$
}

(Accepted 15 November 2002)

\begin{abstract}
The aim of the current study is to explore the potential existence of contextual effects on ethical sensitivity and penalty judgments. In so doing, Turkish female and male business students' ethical judgments for accounting and general business contexts are investigated, along with their penalty judgments in these two settings. The results of this study reveal no significant gender-related differences in ethical judgments on accounting issues, but significant gender differences are observed in general business scenarios. This finding supports the proposition that observed differences of ethical judgments between the genders may be contextual. The results indicate that there is higher ethical awareness for both genders in general business contexts, with females showing stronger ethical sensitivity than males for general business vignettes. In general, males are found to prefer harsher penalties than females for accounting settings and for all penalty choices. Analyses of penalty judgments between the groups of individuals who are more ethically sensitive and who are less ethically sensitive reveals that there exist significant differences between these groups in all penalty choices, with ethically-more-sensitive group participants preferring stronger penalties.
\end{abstract}

KEY WORDS: accounting, ethics, gender, judgment, penalty

\section{INTRODUCTION}

As the ethical and social awareness of corporations becomes an issue of utmost importance, concern for the ethical standards of current and future accountants and executives constitutes a critical agenda for academia and business world alike. Ethics is a domain that invites interdisciplinary research by nature. As documented extensively in a seminal review article (Collins, 2000), the focal issue is the ethical behavior of managers. Majority of the empirical studies pertaining to ethical behavior attempt to depict ethical judgments of individuals, to portray the moral reasoning behind these judgments, and to search for explanations regarding the perceptible differences in judgments. Many studies expound upon social psychology theories and virtue ethics, as well as sociology theories to

^ An earlier version of this paper has been presented at the 5th Symposium on Ethics Research in Accounting, Philadelphia, August 2000. 
explain the differences of ethical judgments in accounting and/or general business contexts (e.g., Ameen et al., 1996; Baker, 1999; Derry, 1989; Douglas and Schwartz, 1999; Jones and Hiltebeitel, 1995; Ponemon, 1995; Wright et al., 1999).

Individual factors such as sex, age, and education have received considerable interest as explanatory factors of differences in ethical behavior, with gender as the single variable receiving more research attention than any other individual trait (Ford and Richardson, 1994). A review of extant research reveals that there are still disparate opinions about the relationship of gender and ethics judgments, although majority of the studies report that females are ethically more sensitive than males (Collins, 2000). The objective of the present study is to enhance our understanding of ethical sensitivity of individuals in two related yet different contexts, i.e., general business and accounting settings. In particular, general business contexts pertain to concerns over environmental issues as well as the effects of power, status, job security, and gender issues in the workplace. Studying ethical sensitivity in such settings where there is no written unified code of ethics provides an intriguing research venue. Accounting, on the other hand, is a field that is governed by written rules of conduct and principles while it continually evolves with the changing demands of the society. Various professional accounting organizations such as the American Institute of Certified Public Accountants, Institute of Management Accounting, and Institute of Internal Auditors have established codes of ethics. As noted by Stanga and Turpen (1991), “... this increased awareness of ethical issues coincides with a tremendous growth in the number of females entering the accounting profession" (p. 740).

From early 1960s to mid-1980s the rate of increase in the number of bachelor's degrees awarded to women was $4,900 \%$ while the rate of increase in number of bachelor's degrees awarded to men was $136 \%$ (Changes in Accounting Education Committee, 1986-1987, 1989, p. 148). By mid-1990s women comprised 55\% of bachelor's degrees in accounting and about half of the U.S. accountants. ${ }^{1}$ National Center for Education Statistics of the U.S. Department of Education report shows that women account for almost $48 \%$ of the students who earn degrees in business and related fields, an incredible increase from about 7,000 in 1968 to 117,493 in $1994 .^{2}$ However, women occupy only $13 \%$ of the partners in accounting firms, indicating much room for gender-ratio improvement.

\footnotetext{
1 Koretz, Gene: 1997, ‘Accounting's Big Gender Switch', Business Week (January 20), http://www.businessweek.com/1997/03/b351034.htm.

2 http://www.aacsb.edu/publications/printnewsline/NL1997/wnbmigrate_1.asp, Newsline Winter 1997.
} 
Thus, accounting also represents an ethically sensitive domain that may be susceptible to potential gender effects. Moreover, the mere presence of codes of ethics may seriously affect perceptions of ethical behavior (Adams et al., 2001).

The current study aims to investigate the presence of systematic differences in ethical judgments of males and females in two contexts that share voracity for ethical issues while being separated by the existence versus lack of specific written codes of ethics. In so doing, it presents aspiring professionals (i.e., business students) with vignettes framed in accounting and general business settings. Ethical dilemmas, presented in the form of vignettes, are used as multi-faceted situations that deny predictability and resolution via the application of concrete rules (Dienhart, 1995; Thorne, 1998). Using such vignettes in accounting and corporate settings, this research examines potential gender differences in (a) ethical sensitivity of future professionals, and (b) penalty judgments deemed appropriate in different contexts. Thus, current work aims to contribute to the existing literature by enhancing our understanding of ethical judgments in closely related but characteristically different domains, as well as investigating the relationship between perceived unethical behavior and penalties that could be imposed in case of ethically questionable actions. It is also worth noting that the majority of research in ethical sensitivity has been carried out in the western or developed world. In contrast, this study aims to determine whether such gender-related differences exist in a developing country, Turkey, which portrays a different cultural mosaic. We next present a short background on Turkish culture to emphasize its differences from the settings typically used in previous studies.

\section{BACKGROUND}

Turkey can be characterized as a transitional country. The geographic characteristic of bridging two continents - Asia and Europe - is reflected in the culture as well. Traditional values are woven with the Western values providing a synthesis of Mediterranean, Balkan, Western and Middle-Eastern cultures (Kongar, 1986). Furthermore, the advancement of technology and communication systems brings the country closer to the Western values. Turkey is entering the new millennium as a European Union member candidate moving in the direction of social and economic liberalization and modernization (Kasaba and Bozdogan, 2000). The liberalization movement that started in the 1980s has been strengthened through the globalization progress in the last decade. As a result, although most of the women in the urban areas are homemakers, $9.8 \%$ of the 
women and $11.8 \%$ of the men in labor force reach executive levels (DIE, 1997). There are two main reasons for these findings: 1) the need to find skilled professionals in newly developing industries that can be supplied by women coming from middle or upper-middle class families of the industrialized segment of the society that are mostly influenced by the Western values (Ozgen, 1997); and 2) the earnings gap between males and females in large industrial companies where females are paid less than their male counterparts (Menguc, 1998). In terms of management practices, Turkish organizations mostly display centralized decision making, portraying a highly personal and leadership-oriented image (Kozan and Ergin, 1999). This transitional framework motivates the need to examine potential gender differences in ethical sensitivity on general business and accounting settings, as discussed next.

\section{SURVEY OF RELEVANT LITERATURE}

Collins (2000) provides an excellent review of the prior empirical research on the relationship of gender and ethics judgments, revealing the disparities in findings. Some studies report that females are ethically more conservative and are concerned more about ethical issues and business ethics, thus arguably reflecting a higher moral development (Arlow, 1991; Ameen et al., 1996; Beltramini et al., 1984; Coate and Frey, 2000; Cohen et al., 1998; Cole and Smith, 1996; Crow et al., 1991; Galbraith and Stephenson, 1993; Harris and Sutton, 1995; Jones and Gautschi, 1988; Kidwell et al., 1987; Larkin, 2000; McCabe et al., 1991; Miesing and Preble, 1985; Peterson et al., 1991; Poorsolton et al., 1991; Ruegger and King, 1992). On the other hand, using business students as participants, Betz et al. (1989) find that males display more willingness to engage in unethical behavior if the result of the action is to bring power or money. Using questionable activities from the students' environment, Ameen et al. (1996) report that female accounting students are "... more sensitive to and less tolerant of unethical behavior" (p. 596). Along the same lines, findings of Malinowski and Berger (1996) indicate that female students display a higher ethical orientation in marketing dilemmas than their male counterparts. In their meta-analysis, Borkowski and Ugras (1998) examine the existing studies that utilized Defining Issues Test (DIT) to investigate ethical beliefs and decision-making. Their results indicate that females exhibit more strict ethical attitudes than males in general. Similarly, Weeks et al. (1999) argue that women professionals appear to possess higher ethical orientation than males regarding the issues related to environment, international trade, promotion practices, and compensation increases. However, they 
also conclude that men display a stricter ethical stance than females, via applications in construction bidding processes and computer software accumulation.

Interestingly, some studies report no significant gender differences in ethical judgments on social or business issues. Barnett and Karson (1989), Davis and Welton (1991), Dubinsky and Levy (1985), Harris (1989), Hegerty and Sims (1978, 1979), McNichols and Zimmerer (1985), Radtke (2000), and Tsalikis and Ortiz-Buonafina (1990) all find no significant differences between men's and women's ethical perceptions or decisions. Rest (1986) reports that the DIT score differences of men and women are minimal, and that gender variable explains only a trivial percentage of the difference in their scores. Similarly, Davis and Welton (1991) investigate whether there are differences in ethical perceptions of male and female graduate and undergraduate business students. Although the authors observe significant differences between graduate and undergraduate students' ethical behavior, they do not find significant differences between male and female students' decisions. In a more recent study, Desphande (1997) examines managers' ethical behavior, concluding that gender is not a decisive factor in ethical perceptions.

A potential explanation for the seemingly contradictory results of extant research is provided by the supposition that gender differences may or may not be revealed depending on context-specific factors. Derry $(1987,1989)$, Dobbins and Platz (1986), Trevino (1992), and Weber (1990) all suggest that contextual characteristics may determine the differences in ethical sensitivity, and that the established professional norms and roles may lead individuals to think in certain ways in particular contexts. Gilligan and Attanuci's (1988) findings of no relationship between the ethical orientation and gender of medical students seem to support the view that the moral reasoning of both genders may be strongly affected by the norms that govern the medical profession. In a similar vein, Stanga and Turpen (1991) detect no significant judgment differences between male and female accounting majors about some financial accounting practices. Confirming these results, Butler and Clark (1999) do not find gender-based differences in decisions based on accounting knowledge.

Extending this line of work, the current research attempts to systematically investigate whether the gender differences in ethical sensitivity could be contextually dependent and whether such potential differences encompass penalty judgments for ethically questionable situations. In particular, the current study examines the judgments made by male and female business students in response to ethical dilemmas covering a variety of situations in accounting and general business contexts. Details of the 
experiment focusing on the potential relationships among gender, ethical sensitivity, penalty judgments, and contextual effects are provided next.

\section{METHOD}

\section{Participants}

Respondents in the study were third-year business majors enrolled in the managerial accounting course at Bilkent University, Turkey.All participants were Turkish, and came from mostly middle or upper-middle class families. Students needed to complete two semesters of financial accounting and two semesters of business courses prior to taking this managerial accounting course. Therefore, the participants were expected to clearly understand the technical content of the accounting vignettes in addition to the general business scenarios. A total of 117 students participated in the study. Forty-eight percent of the participants $(n=56)$ were female, and $52 \%(\mathrm{n}=61)$ were male. The average age was 21 years, with a range between 20 and 26 years.

\section{Ethics Vignettes}

The vignettes used in the current study were constructed mainly from cases, scenarios or vignettes utilized in previous studies (Cohen et al., 1998; Karcher, 1996; Okleshen and Hoyt, 1996; Schminke and Ambrose, 1997; Weeks et al., 1999) or were inspired by Likierman (1989), and Trevino and Nelson (1995) regarding real life dilemmas faced by accountants specifically, and by business people in general. Some of the vignettes were adapted from examples in monographs or text books (i.e., Boatright, 1995; Cottell and Perlin, 1990; Hansen and Mowen, 1992; Konrath, 1996; Mintz, 1992). Each vignette involved a specific ethical dilemma that reflected a realistic business conflict situation leading to a questionable action performed by the individual described in the scenario. The vignettes covered sufficient detail to represent realistic situations, yet care was taken to avoid presenting unduly complex scenarios.

Three pretests were conducted to improve the vignettes. In the first pretest, business faculty completed the questionnaire and commented on the reasonableness and relevance of the vignettes. After the vignettes were modified based on the comments, they were distributed to $\mathrm{PhD}$ and MBA students. During pretests, the respondents were requested to comment on the relevance, and whether the vignettes appeared to lead individuals into a particular type of response. After carefully studying the comments, the vignettes were refined again and tested by professional 
auditors. Finally, the authors reviewed the vignettes in light of all the comments and variability of responses, hence leading to the final version given to the participants (Exemplar vignettes for accounting and business scenarios are presented in Appendix I, and all vignettes are available upon request from the authors).

\section{Procedure}

Participants were informed that they would be requested to read twenty four ethical dilemmas concerning general business and accounting practices (twelve for each type) that they might face in their professional lives, and were asked about their "opinion" regarding the actions of the individual in the scenarios. Student participation was voluntary, and anonymity was assured. Participants were asked to complete a questionnaire that included demographic questions (i.e., their age and gender), along with each vignette followed by questions regarding ethical sensitivity and penalty judgments. In particular, following each vignette, participants were asked to state their opinion about whether the action performed in the scenario was ethical/unethical using a seven-point Likert scale ranging from (1)definitely not ethical, to (7)definitely ethical (Please see Appendix II for a sample form given to participants). This was followed by questions which asked the participants' opinion regarding the penalty that they thought would be appropriate had there been a higher council that ruled the action in the vignette as unethical. Five potential penalties were presented in order of most severe alternative (i.e., the person engaged in the activity should be taken to court), to no penalty (i.e., there is no need for punishment). As can be seen from Appendix II, participants were asked to indicate their degree of agreement with each penalty suggestion using a seven-point Likert scale from (1)definitely disagree, to (7)definitely agree. Participants appeared highly motivated and indicated that it was a very interesting task, and that they had enjoyed working through the vignettes which they found to be very realistic.

\section{RESULTS}

In the analyses, the focus was on exploring: 1) whether male and female students differ in their ethics judgments elicited for accounting and general business contexts; and 2) whether there exists a gender difference in the suggested penalties for accounting and general business settings. Descriptive analyses for each of the two contexts (i.e., "general business" and "accounting") are followed by statistical tests to determine whether 
the differences of opinion between genders, and between contexts are significant. Wilcoxon tests are used to test the statistical significance of the differences between general business and accounting vignettes, and Mann-Whitney-U tests are utilized to investigate the potential differences between males and females. ${ }^{3}$

\section{Ethical Sensitivity}

First, the question of ethical sensitivity is addressed. Examination of Table I reveals that all participants display a stronger ethical orientation in general business vignettes as compared to accounting scenarios (as shown with a significantly lower mean of 3.64 for business as compared to a mean of 4.18 for accounting vignettes; $p=0.0001$ ). Almost $50 \%$ of all participants believed that the actions in general business vignettes were unethical (as conveyed via 1-3 responses for the ethical sensitivity question). In comparison, only 39\% of the participants thought the actions in the accounting scenarios were not ethical. Furthermore, females displayed more ethical awareness for actions in general business settings than males (with means of 3.45 for females and 3.81 for males; $p=0.0007$ ) and $54 \%$ of females and only $46 \%$ of males stated that they did not think the actions in the vignettes were ethical. For accounting contexts, although descriptive analysis indicates that males exhibit less tolerance (42\% think the action is not ethical as opposed to $36 \%$ in females) for the actions of individuals in these vignettes than females (means of 4.09 for males and 4.28 for females), these differences are not found to be statistically significant ( $\mathrm{p}>$ $0.05){ }^{4}$

For both genders, ethical sensitivity appears to be higher in general business contexts as compared to accounting settings (i.e., for females, means of 3.45 for business vs. 4.28 for accounting $(\mathrm{p}=0.0001)$; for males, means of 3.81 for business vs. 4.09 for accounting $(\mathrm{p}=0.0101)$ ).

\footnotetext{
3 Nonparametric methods are used because they provide distribution-free and conservative tests, and hence are statistically more appropriate in situations involving ordinallyscaled data.

4 A repeated measures design was also used to test the ethical sensitivity of the participants to examine any discrepancies with the non-parametric analysis findings. The results reveal that the type of vignette - accounting vs. general business - is significant (Wilks' Lambda $\left.=0.65, \mathrm{~F}_{1,99}=53.91, \mathrm{p}<0.0001\right)$. Furthermore, the tests show significant interaction between "gender" and "type of vignette" $(\mathrm{p}=0.0002)$. The repeated measures analysis of variance shows no significant interaction between "gender" and "type of vignette" for the accounting scenarios $(\mathrm{p}>0.05)$, but indicates a significant interaction between these two variables for the general business cases $(p=0.0077)$. Throughout the remaining analyses, repeated measures were also utilized to check for consistency with the non-parametric test results.
} 
TABLE I

Ethical sensitivity

\begin{tabular}{llllclll}
\hline \multicolumn{2}{l}{ A. General Business Vignettes } \\
\hline & \# Responses* & Mean & St. Dev. & Median & $1-3 \%$ & $4 \%$ & $5-7 \%$ \\
\hline All Students & 1397 & $3.6385^{\mathrm{a}}$ & 2.0520 & 4 & 49.5 & 14.5 & 35.9 \\
Females & 669 & $3.4469^{\mathrm{a}}$,b & 2.0449 & 3 & 54.0 & 13.6 & 32.4 \\
Males & 728 & $3.8146^{\mathrm{c}}$ & 2.0442 & 4 & 45.5 & 15.4 & 39.1 \\
\hline
\end{tabular}

B. Accounting Vignettes

\begin{tabular}{lccccccc}
\hline & \# Responses* & Mean & St. Dev. & Median & $1-3 \%$ & $4 \%$ & $5-7 \%$ \\
\hline All Students & 1392 & 4.1796 & 1.9883 & 4 & 38.9 & 15.5 & 45.5 \\
Females & 669 & 4.2810 & 1.9929 & 4 & 35.9 & 15.8 & 48.3 \\
Males & 723 & 4.0857 & 1.9808 & 4 & 41.8 & 15.2 & 43.0 \\
\hline
\end{tabular}

${ }^{*}$ Responses on a $1-7$ scale with $1=$ definitely unethical; $7=$ definitely ethical.

${ }^{a}$ significant difference between general business and accounting; $\mathrm{p}<0.001$.

$\mathrm{b}$ significant difference between females and males; $\mathrm{p}<0.001$.

${ }^{\mathrm{c}}$ significant difference between general business and accounting; $\mathrm{p}<0.05$.
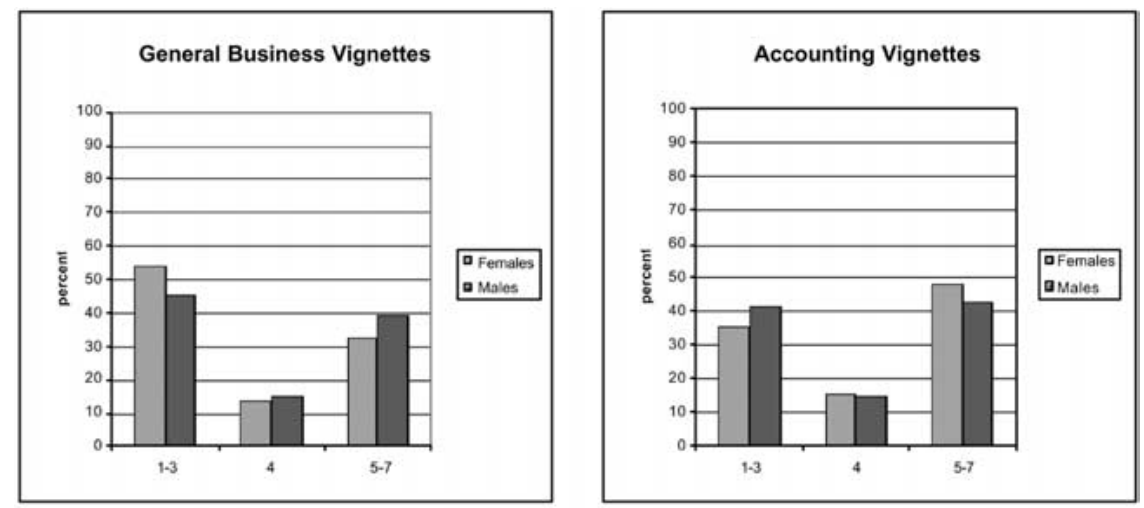

These differences can be clearly observed in Table I; with $54 \%$ of females conveying unethical judgments (via 1-3 reports in their answers to this question) in business contexts, as opposed to $36 \%$ of such responses in their judgments for accounting settings. Similarly, although $46 \%$ of males give unethical judgments in general business vignettes, this percentage drops to $42 \%$ in accounting vignettes. 
TABLE II

Penalty 1: 'SHOULD BE TAKEN TO COURT'

\begin{tabular}{lclccccc}
\hline \multicolumn{2}{l}{ A. General Business Vignettes } \\
\hline & \# Responses* & Mean & St. Dev. & Median & $1-3 \%$ & $4 \%$ & $5-7 \%$ \\
\hline All Students & 1359 & 2.5666 & 1.9477 & 2 & 72.0 & 9.1 & 24.0 \\
Females & 642 & 2.3333 & 1.7746 & 1 & 77.3 & 8.7 & 23.6 \\
Males & 717 & 2.7754 & 2.0696 & 2 & 67.4 & 9.3 & 24.4 \\
\hline
\end{tabular}

B. Accounting Vignettes

\begin{tabular}{lcllcccc}
\hline & \# Responses* & Mean & St. Dev. & Median & $1-3 \%$ & $4 \%$ & $5-7 \%$ \\
\hline All Students & 1365 & 2.7099 & 2.1486 & 2 & 69.7 & 6.3 & 18.9 \\
Females & 649 & 2.6672 & 2.1524 & 1 & 70.4 & 6.0 & 14.0 \\
Males & 716 & $2.7486^{\mathrm{b}}$ & 2.1460 & 2 & 69.0 & 6.6 & 23.3 \\
\hline
\end{tabular}

${ }^{*}$ Responses on a 1-7 scale with $1=$ definitely disagree; $7=$ definitely agree.

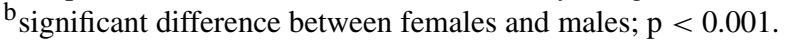

\section{Penalty Judgments}

The above analyses were repeated for each of the suggested penalties described in the questionnaire. The most severe penalty involved deciding that the individual should be taken to court (with a response scale of 1 : definitely disagree, to 7 : definitely agree). As depicted in Table II, although the majority of the students did not use judgments favoring this penalty (responses of 1-3), both males and females seemingly suggested this penalty relatively more often in general business settings as compared to accounting contexts, however, no statistically significant differences could be discerned. Interestingly, it appears that males tend to impose this severe penalty more than females, especially in the given accounting contexts $(\mathrm{p}=0.0003)$.

Next penalty demands that the action of the individual "should be publicized." Although $32 \%$ of all students agree with this penalty in general business settings, this percentage is reduced to $27 \%$ in the accounting settings. We also observe different preferences of males and females as presented in Table III. Females seemed to agree with this penalty more in general business contexts as opposed to the accounting contexts $(\mathrm{p}=$ 0.0002). Although males did not significantly differentiate between the two contexts, they appeared to prefer this penalty more than the females do in accounting contexts $(\mathrm{p}=0.0001)$. 
TABLE III

Penalty 2: 'SHOULD BE PUBLICIZED’

\begin{tabular}{llllllll}
\hline \multicolumn{1}{l}{ A. General Business Vignettes } & & & & & & \\
\hline & \# Responses* & Mean & St. Dev. & Median & $1-3 \%$ & $4 \%$ & $5-7 \%$ \\
\hline All Students & 1368 & $3.2420^{\mathrm{c}}$ & 2.3142 & 2 & 59.2 & 8.6 & 32.2 \\
Females & 651 & $3.1982^{\mathrm{a}}$ & 2.3460 & 2 & 60.2 & 7.7 & 32.1 \\
Males & 717 & 3.2817 & 2.2858 & 3 & 58.3 & 9.3 & 32.4 \\
\hline
\end{tabular}

B. Accounting Vignettes

\begin{tabular}{lccccccc}
\hline & \# Responses* $^{*}$ & Mean & St. Dev. & Median & $1-3 \%$ & $4 \%$ & $5-7 \%$ \\
\hline All Students & 1361 & 3.0095 & 2.1152 & 2 & 62.9 & 9.8 & 27.3 \\
Females & 640 & 2.6250 & 1.9509 & 2 & 70.9 & 9.7 & 19.4 \\
Males & 721 & $3.3509^{\mathrm{b}}$ & 2.1967 & 3 & 55.8 & 9.9 & 34.3 \\
\hline
\end{tabular}

* Responses on a 1-7 scale with $1=$ definitely disagree; 7 = definitely agree.

${ }^{a}$ significant difference between general business and accounting; $\mathrm{p}<0.001$.

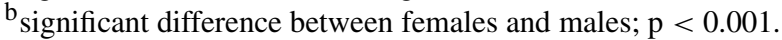

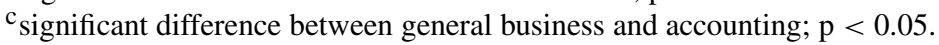

The third penalty suggested is that the individual in the vignette "should be asked to resign." Only about $22 \%$ of all students seemingly agree with this penalty in both accounting and general business settings. Although there is no statistically significant difference between the two contexts for either gender, males significantly indicate a higher agreement with this penalty than females in accounting settings $(\mathrm{p}=0.0001)$.

The fourth penalty states that the individual who performed the unethical action in a vignette "should be issued a warning." As shown in Table V, all participants showed the highest preference for this penalty in both accounting (35\% of the judgments were between 5 and 7) and general business settings (43\% of assessments were in the range of 57). However, females appeared to judge the actions in general business settings significantly more harshly than the actions in accounting settings $(\mathrm{p}=0.0001)$, a result that is not observed for the males. The findings also show that there is no significant difference between the decisions of males and females in general business contexts for this penalty. However, in accounting settings, males concurred more than the females did with this penalty in $(\mathrm{p}=0.0045)$.

The last available choice for penalties is that no penalty should be imposed. As displayed in Table VI, males and females were found to significantly differ in their responses for the given accounting cases (with 
TABLE IV

Penalty 3: 'SHOULD BE ASKED TO RESIGN'

\begin{tabular}{llllllll}
\hline A. General Business Vignettes & & & & & & \\
\hline & \# Responses* & Mean & St. Dev. & Median & $1-3 \%$ & $4 \%$ & $5-7 \%$ \\
\hline All Students & 1362 & 2.7159 & 2.0090 & 2 & 67.9 & 10.3 & 21.8 \\
Females & 647 & 2.6491 & 1.9959 & 2 & 70.2 & 9.1 & 20.7 \\
Males & 715 & 2.7762 & 2.0203 & 2 & 65.9 & 11.3 & 22.8 \\
\hline
\end{tabular}

B. Accounting Vignettes

\begin{tabular}{llllcrrr}
\hline & \# Responses* & Mean & St. Dev. & Median & $1-3 \%$ & $4 \%$ & $5-7 \%$ \\
\hline All Students & 1359 & 2.6946 & 1.9629 & 2 & 68.0 & 10.4 & 21.6 \\
Females & 642 & 2.4050 & 1.8103 & 2 & 74.8 & 8.9 & 16.4 \\
Males & 717 & $2.9540^{\mathrm{b}}$ & 2.0570 & 2 & 61.9 & 11.9 & 38.1
\end{tabular}

*Responses on a 1-7 scale with $1=$ definitely disagree; 7 = definitely agree.

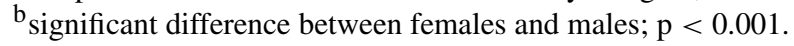

TABLE V

Penalty 4: 'SHOULD BE ISSUED WARNING'

\begin{tabular}{llllllll}
\hline \multicolumn{2}{l}{ A. General Business Vignettes } & & & & & \\
\hline & \# Responses* & Mean & St. Dev. & Median & $1-3 \%$ & $4 \%$ & $5-7 \%$ \\
\hline All Students & 1371 & $3.8621^{\mathrm{a}}$ & 2.3595 & 4 & 46.6 & 10.3 & 43.1 \\
Females & 653 & $3.9831^{\mathrm{a}}$ & 2.3966 & 4 & 45.2 & 8.6 & 46.2 \\
Males & 718 & 3.7521 & 2.3214 & 4 & 47.9 & 11.8 & 40.3 \\
\hline
\end{tabular}

B. Accounting Vignettes

\begin{tabular}{llllclll}
\hline & \# Responses* & Mean & St. Dev. & Median & $1-3 \%$ & $4 \%$ & $5-7 \%$ \\
\hline All Students & 1360 & 3.4390 & 2.2076 & 3 & 53.2 & 12 & 34.9 \\
Females & 641 & 3.2636 & 2.1989 & 3 & 57.6 & 10.9 & 31.5 \\
Males & 719 & $3.5953^{\mathrm{b}}$ & 2.2051 & 4 & 49.2 & 12.9 & 37.8 \\
\hline
\end{tabular}

*Responses on a 1-7 scale with 1 = definitely disagree; 7 = definitely agree.

${ }^{a}$ significant difference between general business and accounting; $p<0.001$.

$\mathrm{b}$ significant difference between females and males; $\mathrm{p}<0.005$. 
TABLE VI

Penalty 5: 'NO PENALTIES SHOULD BE IMPOSED'

\begin{tabular}{lcllllll}
\hline \multicolumn{2}{l}{ A. General Business Vignettes } \\
\hline & \# Responses* & Mean & St. Dev. & Median & $1-3 \%$ & $4 \%$ & $5-7 \%$ \\
\hline All Students & 1352 & 3.7884 & 2.3371 & 4 & 39.3 & 12.7 & 51.3 \\
Females & 640 & 3.6781 & 2.3642 & 3 & 51.6 & 9.5 & 38.9 \\
Males & 712 & 3.8876 & 2.3097 & 4 & 36.4 & 9.7 & 53.9 \\
\hline
\end{tabular}

B. Accounting Vignettes

\begin{tabular}{lcllcccc}
\hline & \# Responses & Mean & St.Dev. & Median & $1-3 \%$ & $4 \%$ & $5-7 \%$ \\
\hline All Students & 1351 & 3.9334 & 2.2868 & 4 & 45.9 & 12.1 & 42.0 \\
Females & 640 & $4.0625^{\mathrm{a}, \mathrm{b}}$ & 2.3554 & 4 & 44.5 & 11.9 & 43.6 \\
Males & 711 & 3.8172 & 2.2468 & 4 & 47.1 & 12.4 & 40.5 \\
\hline
\end{tabular}

* Responses on a 1-7 scale with $1=$ definitely disagree; 7 = definitely agree.

${ }^{\mathrm{a}}$ significant difference between general business and accounting; $\mathrm{p}<0.005$.

$\mathrm{b}$ significant difference between females and males; $\mathrm{p}<0.05$.

females agreeing more with this suggestion in comparison to males, $\mathrm{p}=$ 0.0478 ) but not for general business cases. Almost 54\% of the males strongly believed that no penalty was necessary in general business cases, but $47 \%$ of them thought there should be some kind of penalty in the accounting cases. Although females' results showed that their decision depended on whether the action related to general business or accounting contexts (with females agreeing less with this suggestion in general business as opposed to accounting settings, $p=0.0022$ ), males did not distinguish between the two contexts.

Our next analysis involved investigation of the potential differences in penalty judgments that exist between the ethically more sensitive and ethically less sensitive groups, as well as the possible gender differences in each group. In grouping the participants, students who had given judgments between 1-3 for the ethical sensitivity question were classified as "ethically sensitive"; while those who had judgments of 5-7 were classified as "ethically less sensitive." Also, students with responses of 1-3 for penalty questions were grouped into the "Disagree" category, while those with 5-7 were grouped into the "Agree" category, for each of the penalty considerations [Note that the percentages for the disagree and the agree categories within a penalty judgment do not add up to $100 \%$, since the students giving a judgment of 4 (indicating indecision about whether 
TABLE VII

RELATIVE FREQUENCIES OF PENALTY JUDGMENTS GIVEN BY ETHICALLY-SENSITIVE VS. ETHICALLY-LESS-SENSITIVE GROUPS

\begin{tabular}{lllllllrr}
\hline & & \multicolumn{3}{c}{ Ethically Sensitive } & & \multicolumn{3}{c}{ Ethically Less Sensitive } \\
\cline { 8 - 9 } & & Female & Male & ALL & & Female & Male & ALL \\
\hline Take to court & Disagree & $62.0 \%$ & $52.3 \%$ & $56.6 \%$ & $89.4 \%$ & $83.0 \%$ & $86.2 \%$ \\
$a, b, d, e$ & Agree & $26.2 \%$ & $37.7 \%$ & $32.7 \%$ & $6.0 \%$ & $13.1 \%$ & $9.6 \%$ \\
Publicize & Disagree & $52.1 \%$ & $39.3 \%$ & $44.9 \%$ & $87.0 \%$ & $73.3 \%$ & $80.1 \%$ \\
$a, b, c, d, e$ & Agree & $37.7 \%$ & $50.8 \%$ & $45.1 \%$ & $7.0 \%$ & $21.2 \%$ & $14.2 \%$ \\
Ask to Resign & Disagree & $52.1 \%$ & $43.2 \%$ & $47.1 \%$ & $89.8 \%$ & $79.4 \%$ & $84.6 \%$ \\
$a, b, c, d, e$ & Agree & $34.3 \%$ & $45.9 \%$ & $40.8 \%$ & $5.3 \%$ & $11.8 \%$ & $8.5 \%$ \\
Issue Warning & Disagree & $30.3 \%$ & $25.1 \%$ & $27.4 \%$ & $81.2 \%$ & $73.3 \%$ & $77.2 \%$ \\
$a, d, e$ & Agree & $55.1 \%$ & $61.1 \%$ & $58.5 \%$ & $14.2 \%$ & $19.2 \%$ & $16.7 \%$ \\
No Penalty & Disagree & $63.5 \%$ & $68.5 \%$ & $66.3 \%$ & $31.8 \%$ & $31.5 \%$ & $31.6 \%$ \\
$a, d, e$ & Agree & $24.8 \%$ & $21.8 \%$ & $23.1 \%$ & $60.7 \%$ & $60.0 \%$ & $60.4 \%$ \\
\hline
\end{tabular}

$\overline{a \text { significant difference between ethically-sensitive and ethically-less-sensitive groups }}$ across all participants (Wilcoxon; $\mathrm{p}<0.001$ ).

${ }^{b}$ significant difference between genders within the ethically-sensitive group (MannWhitney; $\mathrm{p}<0.05$ ).

${ }^{c}$ significant difference between genders within the ethically-less-sensitive group (MannWhitney; $\mathrm{p}<0.05)$.

$d_{\text {significant difference between ethically-sensitive and ethically-less-sensitive groups }}$ within females (Mann-Whitney; $\mathrm{p}<0.001$ ).

${ }^{e}$ significant difference between ethically-sensitive and ethically-less-sensitive groups within males (Mann-Whitney; $\mathrm{p}<0.001$ ).

to agree or not with the suggested penalty option) were excluded from the tables to highlight the differences in agreement/disagreement regarding penalty judgments]. Table VII presents the result of this analysis.

The results reveal that there exist significant differences between the penalty judgments of the ethically-sensitive and the ethically-less-sensitive groups in all penalty categories (all $\mathrm{p}=0.0001$ ). Our findings confirm the expectation that ethically more sensitive individuals may display a greater tendency to impose higher penalties in cases of ethical infringements. Furthermore, results demonstrate significant differences between males and females of the ethically sensitive group in their penalty decisions for the stronger penalties. In particular, it is found that the males favor stronger penalties (i.e., taking to court $(\mathrm{p}=0.0113)$, publicizing the action $(\mathrm{p}=0.0002)$, and asking to resign $(\mathrm{p}=0.0012))$ more than the females. 
However, no significant differences are found between males and females of the ethically sensitive group for the light/no penalty suggestions.

In the ethically less sensitive group, significant gender differences are only found for the penalty to "publicize" $(\mathrm{p}=0.0070)$, and the "ask to resign" penalty $(\mathrm{p}=0.0341)$. Again males tended to impose stronger penalties than females in these categories.

The results of analysis within each gender indicate significant differences of opinion regarding all penalty categories $(p=0.0001$ for all comparisons). For both females and males, ethically-sensitive group is found to (1) disagree about twice as much with the no penalty suggestion, implying they think a penalty in some form should be given; and (2) agree significantly more with each of the stated penalties in comparison to the ethically-less-sensitive group.

\section{DISCUSSION}

Ethical sensitivity has been defined as the ability to "... recognize the ethical nature of a situation in a professional context" (Shaub et al., 1993, p. 146), “... ability to recognize ethical issues" (Hebert et al., 1990 , p. 141), and as the "... ability to recognize an issue and its ethical dimensions, when applicable" (Wright et al., 1998, p. 37). To fill a void in the extant literature on gender differences, current work has focused on contextual contingencies in relation to ethical sensitivity and resultant penalty judgments of aspiring professionals in Turkey.

The results of this study reveal no gender differences in ethical judgments on accounting issues, but significant gender effects are observed in general business scenarios. These findings are congruent with the proposition that observed differences in ethical sensitivity between the genders may be contextual. The participants in the study were third-year business undergraduates who had completed their major business and accounting courses. Given that the age range and backgrounds of the students did not display much variation, the results could imply that the lack of gender differences in accounting contexts may be due to the training shared by all participants.

Betz et al. (1989) provide a thorough review of the two alternative explanations for gender differences in ethical behavior: the gender socialization approach (where sexes are assumed to bring their own values and traits to their work roles), and the structural approach (where differences due to early socialization and requirements of social roles between men and women will be dominated by the rewards/costs associated with occupational roles; thus, the two genders are expected to react similarly in same 
occupational environments). The results of this study appear to support the gender socialization approach in the general business context, while supporting the structural approach in the accounting setting. According to the gender socialization approach, males place more emphasis on achievement and success, breaking some rules in order to succeed, which may in turn explain the findings with general business scenarios. Structural approach, on the other hand, suggests that females and males become alike when they go through the same training, and thus respond similarly in the same professional setting. This approach seems to provide an explanation for the lack of differences in the accounting context.

Furthermore, the results coincide with Smith and Oakley's (1997) findings in the sense that in a setting that is dominated by written rules of conduct and principles, the difference between the genders disappears. Accounting discipline operates within its well-established almost global rules and regulations that are transmitted to the students through relevant courses. Although the participants in this study are not accounting experts, the general "rules and regulations" environment that governs the accounting discipline seems to have been conveyed to students. However, in general business situations, no such identifiable and common set of rules has yet been established (even though it is argued that moral rules are ingrained into business contexts (Spurgin, 2000)). Interestingly, Bartlett and Preston (2000) find that employees doubt codes of general business ethics "... because there is no good and bad between which to choose. The choice is between success and failure" (p. 199).

The findings indicate that there is higher ethical awareness for both genders in general business contexts. Also, females show stronger ethical orientation than males for general business vignettes, but their penalty judgments are not significantly different than males for these cases. In general, males prefer higher penalties than females for accounting settings and for all penalty choices. One plausible explanation might come from Gilligan's (1982) assertions that men are more likely to rely on justice, rules and individual rights in their ethical judgments, whereas women tend to reflect on relationships, caring, and compassion. Another line of explanation can be found in the decision rules utilized by males and females. Prior research has shown that women usually use utilitarian rules, and men usually choose rules to maximize own self-interest (Eaton and Giacomino, 2001; Galbraith and Stephenson, 1993). Following the axioms of gender socialization theory, it is possible to state that men conceive the profession they are in as a game that has to be won, and thus, believe that the individual should be made to suffer a cost if the game is lost (i.e., if one breaks the rules to reach a goal and is caught, then (s)he 
must be penalized). One other explanation can be found in the conflict resolution practices in Turkey where managers rely on their authority in solving problems with subordinates. In other words, there exists a strong leadership environment with limited delegation of authority and in which people avoid direct confrontation (Kozan and Ergin, 1999). Hence, if a subordinate or peer breaks an unwritten rule, it is expected that s/he should bear the consequences.

Analyses of penalty judgments between the groups of individuals who are more ethically sensitive and who are less ethically sensitive reveals that there exist significant differences between these groups in all penalty choices. As one would expect, ethically more sensitive group prefers stronger penalties. Within group analysis shows that females and males differ mainly in stronger penalty choices and that males prefer more severe penalties. These findings may have important implications for group decision-making and leadership training in organizations, where the two genders need to conciliate their differences to make effective decisions.

Our third research question involved the cultural transfer of genderbased differences in ethical judgments. The findings of this research appear to suggest that such differences tend to be universal albeit its small sample size. A similar observation was made by Okleshen and Hoyt (1996) in their comparison of U.S. and New Zealand students. The results of this study is definitely limited in that it has one sample of students from one university in one developing country, however it provides an additional discussion to the issues that were investigated by similar studies in other parts of the world. Future cross-cultural work that uses the same instrument is definitely needed to enhance our understanding of potential sociological effects on ethics judgments and related aspects before a definitive conclusion can be reached.

It may also be argued that the influx of females into the global business community could have serious repercussions in organizational settings, with the effects perhaps most evident in cross-cultural frameworks. As we enter the new millennium, national borders are beginning to lose their significance and the observed similarities in such judgments will be helpful in reshaping and refining the rules of business and accounting alike. Ethical sensitivities and decision-makers' reactions to ethically plausible situations will undoubtedly play critical roles in redefining corporate cultures and molding tomorrow's business world (Enderle, 1997; Michalos, 1997). 


\section{ACKNOWLEDGEMENTS}

We would like to acknowledge the helpful comments and suggestions of Professor Gail Wright, two anonymous reviewers, and the participants of the 5th Symposium on Ethics Research in Accounting (Philadelphia, August 2000).

\section{APPENDIX I}

\section{EXEMPLAR VIGNETTES FOR GENERAL BUSINESS AND ACCOUNTING CONTEXTS}

\section{A. GENERAL BUSINESS VIGNETTE}

Sybil started to work as the marketing manager in a new firm about a month ago. The new firm is the competitor of her old firm in which she worked for 11 years. One day, the president of the new firm asks her to prepare a report that compares the distribution channels of the two firms. Sybil says she cannot prepare such a report because it would contain confidential information about her previous firm. However, the president argues that their firm is ready to provide any information requested, and thus, he expects the other firms should do the same. Moreover, he stresses that her loyalty is to the new firm. Sybil prepares the report and gives it to the president.

\section{B. ACCOUNTING VIGNETTE}

Sam has been working in $\mathrm{K} \& \mathrm{~S}$ auditing firm for the last two years. He is married with two kids. Although his wife is also working, their monthly salaries are only enough to cover their monthly expenses. During the audit of one of their important clients, Tosnini Records, Sam notices that the sales manager of Tosnini donates little amounts to the radio stations in the city to encourage them to play their records. The sales manager tells Sam that all record manufacturers donate to the radio stations, and if Tosnini would not donate, they would be at a disadvantage. $\mathrm{He}$ also states that, although there is a law to prohibit such donations, it is not enforced. After listening to his explanations, Sam studies the law and its enforcement practices, and realizes that the manager is correct about the enforcement issue. Thus, he decides not to mention this issue to his supervisors. 
APPENDIX II

SAMPLE FORM

\section{Vignette 1: Please answer all the questions}

*The behavior depicted

in the vignette is:

DEFINITELY

NOT ETHICAL
DEFINITELY

ETHICAL

7

*If there was a higher council evaluating the issues that are similar to the ones in the above vignette, and if this council has decided that the behavior depicted in the vignette was unethical, please indicate the extent of your agreement with each of the following penalties:

DEFINITELY

DISAGREE
DEFINITELY

AGREE

$\begin{array}{llllllll}\text { TAKE TO COURT } & 1 & 2 & 3 & 4 & 5 & 6 & 7 \\ \text { PUBLICIZE } & 1 & 2 & 3 & 4 & 5 & 6 & 7 \\ \text { ASK TO RESIGN } & 1 & 2 & 3 & 4 & 5 & 6 & 7 \\ \text { ISSUE WARNING } & 1 & 2 & 3 & 4 & 5 & 6 & 7 \\ \text { NO PENALTY } & 1 & 2 & 3 & 4 & 5 & 6 & 7\end{array}$




\section{REFERENCES}

Adams, J. S., A. Tashchian and T. H. Lee: 2001, 'Codes of Ethics as Signals for Ethical Behavior', Journal of Business Ethics 29(3), 199-211.

Ameen, E. C., D. M. Guffey and J. J. McMillan: 1996, 'Gender Differences in Determining the Ethical Sensitivity of Future Accounting Professionals', Journal of Business Ethics 15, 591-597.

Arlow, P.: 1991, 'Personal Characteristics on College Students' Evaluations of Business Ethics and Corporate Social Responsibility', Journal of Business Ethics 10, 63-69.

Baker, R. C.: 1999, 'Theoretical Approaches to Research on Accounting Ethics', in L. A. Ponemon (ed.), Research on Accounting Ethics, Vol. 5, JAI Press Inc., CT, pp. 115-134.

Barnett, J. H. and M. J. Karson: 1989, 'Managers, Values, and Executive Decisions: An Exploration of the Role of Gender, Career Stage, Organizational Level, Function and the Importance of Ethics, Relationships, and Results in Managerial Decision Making', Journal of Business Ethics 8, 747-771.

Bartlett, A. and D. Preston: 2000, 'Can Ethical Behavior Really Exist in Business', Journal of Business Ethics 23(2), 199-209.

Beltramini, R. F, R. A. Peterson and G. Kozmetsky: 1984, 'Concerns of College Students Regarding Business Ethics', Journal of Business Ethics 3, 195-200.

Betz, M., L. O'Connell and J. M. Shepard: 1989, 'Gender Differences in Proclivity for Unethical Behavior, Journal of Business Ethics 8, 321-324.

Boatright, J. R.: 1995, Cases in Ethics and the Conduct of Business, Prentice Hall, Englewood, NJ.

Borkowski, S. and Y. J. Ugras: 1998, 'Business Students and Ethics: A Meta-Analysis', Journal of Business Ethics 17, 1117-1127.

Butler, J. B., and R. L. Clark: 1999, 'Values, Gender and Skill Misrepresentation: A Laboratory Experiment', in L. A. Ponemon (ed.), Research on Accounting Ethics, Vol. 5, JAI Press Inc., CT, pp. 145-161.

Changes in Accounting Education Committee: 1986-1987, 1989, 'Report of the Changes in Accounting Education Committee 1986-1987', in J. J. Schultz, Jr. (ed.), Reorienting Accounting Education: Reports on the Environment, Professoriate, and Curriculum of Accounting, American Accounting Association, Sarasota, Florida.

Coate, C. J. and K. J. Frey: 2000, 'Some Evidence on the Ethical Disposition of Accounting Students: Context and Gender Implications', Teaching Business Ethics 4, 379-404.

Cohen, J., L. W. Pant and D. J. Sharp: 1998, 'The Effect of Gender and Academic Discipline Diversity on the Ethical Evaluations, Ethical Intentions, and Ethical Orientation of Potential Public Accounting Recruits', Accounting Horizons 12(3), 250-270.

Cole, B. C. and D. L. Smith: 1996, 'Perceptions of Business Ethics: Students vs. Business People', Journal of Business Ethics 15, 889-896.

Collins, Denis: 2000, 'The Quest to Improve the Human Condition: The First 1500 Articles Published in Journal of Business Ethics', Journal of Business Ethics 26, 1-73.

Cottell, P. G. and T. M. Perlin: 1990, Accounting Ethics: A Practical Guide For Professionals, Quorum Books, NY.

Crow, S., L. Fok, S. Hartman and D. Payne, 1991: 'Gender and Values: What is the Impact of Decision-Making?', Sex Roles 25(3/4), 255-268.

Davis, J. R. and R. E. Welton: 1991, 'Professional Ethics: Business Students' Perceptions', Journal of Business Ethics 10, 451-463.

Derry, R.: 1987, 'Moral Reasoning in Work-Related Conflicts', in W. C. Frederick (ed.), Research in Corporate Social Performance and Policy, Vol. 9, JAI Press, Greenwich, CT. 
Derry, R.: 1989, 'An Empirical Study of Moral Reasoning Among Managers', Journal of Business Ethics 8, 855-862.

Deshpande, S. P.: 1997, 'Managers' Perception of Proper Ethical Conduct: The Effect of Sex, Age, and Level of Education', Journal of Business Ethics 16, 79-85.

DIE (State Statistics Institute-Turkey), www.die.gov.tr.

Dienhart, J.: 1995, 'Rationality, Ethical Codes and an Egalitarian Justification for Ethical Expertise', Business Ethics Quarterly 5, 419-450.

Dobbins, G. H. and S. J. Platz: 1986, 'Sex Differences in Leadership: How Real are They?', Academy of Management Review 11(1), 118-127.

Douglas, P. C. and B. N. Schwartz: 1999, 'Values as the Foundation for Moral Judgments: Theory and Evidence in an Accounting Context', in L. A. Ponemon (ed.), Research on Accounting Ethics, Vol. 5, JAI Press Inc., CT, pp. 3-20.

Dubinsky, A. J. and M. Levy: 1985, 'Ethics in Retailing: Perceptions of Retail Salespeople', Journal of Academy of Marketing Science 13(1), 1-16.

Eaton, T. V. and D. E. Giacomino: 2001, 'An Examination of Personal Values: Differences between Accounting Students and Managers and Differences between Genders', Teaching Business Ethics 5, 213-229.

Enderle, G.: 1997, 'A Worldwide Survey Business Ethics in the 1990s', Journal of Business Ethics 16, 1475-1483.

Ford, R. C. and W. D. Richardson: 1994, 'Ethical Decision Making: A Review of the Empirical Literature', Journal of Business Ethics 13, 205-221.

Galbraith S. and H. B. Stephenson: 1993, 'Decision Rules Used by Male and Female Business Students in Making Ethical Value Judgments: Another Look', Journal of Business Ethics 12, 227-233.

Gilligan, C.: 1982, In a Different Voice. Harvard University Press, Cambridge, MA.

Gilligan, C. and J. Attanuci: 1988, 'Two Moral Orientations: Gender Differences aAnd Similarities', Merrill-Palmer Quarterly 34, 223-237.

Hansen, D. R. and M. M. Mowen: 1992, Management Accounting, 2nd ed., South-Western Publication Co., Cincinnati, OH.

Harris, J. R.: 1989, 'Ethical Values and Decision Processes of Male and Female Business Students', Journal of Business Ethics 8, 234-238.

Harris, J. R and C. D. Sutton: 1995, 'Unraveling the Ethical Decision-Making Process: Clues From an Empirical Study Comparing Fortune 1000 Executives and MBA Students', Journal of Business Ethics 14, 805-817.

Hebert, P., E. M. Meslin, E. V. Dunn, N. Byrne and S. R. Reid: 1990, 'Evaluating Ethical Sensitivity in Medical Students: Using Vignettes as an Instrument', Journal of Medical Ethics 16, 141-145.

Hegarty, W. H. and H. P. Sims, Jr.: 1978, 'Some Determinants of Unethical Decision Behavior: An Experiment', Journal of Applied Psychology 63 (August), 451-457.

Hegarty, W. H. and H. P. Sims, Jr.: 1979, 'Organizational Philosophy, Policies, and Objectives Related to Unethical Decision Behavior: A Laboratory Experiment', Journal of Applied Psychology 64 (June), 331-338.

Jones, S. K. and K. M. Hiltebeitel: 1995, 'Organizational Influence in a Model of Decision Process of Accountants', Journal of Business Ethics 14, 417-431.

Jones, T. M. and F. H. Gautschi, II: 1988, 'Will the Ethics of Business Change? A Survey of Future Executives', Journal of Business Ethics 7, 231-248.

Karcher, J.: 1996, 'Auditors' Ability to Discern the Presence of Ethical Problems', Journal of Business Ethics 15, 1033-1050. 
Kasaba, R. and S. Bozdogan: 2000, 'Turkey at a Crossroad', Journal of International Affairs 54(1), 1-20.

Kidwell, J., R. Stevens and A. Bechke: 1987, 'Differences in Ethical Perceptions Between Male and Female Managers: Myth or Reality?', Journal of Business Ethics 6, 451-457.

Kongar, Emre: 1986, 'Turkey's Cultural Transformation', in G. Renda and C. M. Kortepeter (eds.), The Transformation of Turkish Culture, The Kingston Press Inc., Princeton, NJ, pp. 19-68.

Konrath, L. F.: 1996, Auditing Concepts and Applications: A Risk Analysis Approach, 3rd ed., West Publishing Co., Minneapolis/St. Paul, MN.

Kozan, M. K. and C. Ergin: 1999, 'Third Party Role in Conflict Management in Turkish Organizations', Human Organizations 58(4), 405-415.

Larkin, J. M.: 2000, 'The Ability of Internal Auditors to Identify Ethical Dilemmas', Journal of Business Ethics 23(4), 401-409.

Likierman, A.: 1989, 'Ethical Dilemmas for Accountants: A United Kingdom Perspective', Journal of Business Ethics 8, 617-629.

Malinowski, C. and K. A. Berger: 1996, 'Undergraduate Student Attitudes About Hypothetical Marketing Dilemmas', Journal of Business Ethics 15, 525-535.

McCabe, D., J. Dukerich and J. Dutton: 1991, 'Context, Values and Moral Dilemmas: Comparing the Choices of Business and Law School Students', Journal of Business Ethics 10, 951-960.

McNichols, C. W. and T. W. Zimmerer: 1985, 'Situational Ethics: An Empirical Study of Differentiators of Student Attitudes', Journal of Business Ethics 4, 175-180.

Menguc, B.: 1998, 'The Earnings Gap Between Male and Female Sales Managers', Industrial Marketing Management 27, 385-400.

Michalos, A. C.: 1997, 'Issues For Business Ethics in the Nineties and Beyond', Journal of Business Ethics 16, 219-230.

Miesing, P. and J. F. Preble: 1985, 'A Comparison of Five Business Philosophies', Journal of Business Ethics 4, 465-476.

Mintz, S.: 1992, Cases in Accounting Ethics and Professionalism, McGraw Hill, NY.

Okleshen, M. and R. Hoyt: 1996, 'A Cross Cultural Comparison of Ethical Perspectives and Decision Approaches of Business Students: United States of America versus New Zealand', Journal of Business Ethics 15, 537-549.

Ozgen, Z.: 1997, ‘Turkish Women Won't Go Back!', Woman and Earth Almanac 5(1), $8-13$.

Peterson, R., R. Beltramini and G. Kozmetsky: 1991, 'Concerns of College Students Regarding Business Ethics: A Replication', Journal of Business Ethics 10, 733-738.

Ponemon, L. A.: 1995, 'The Objectivity of Accountants' Litigation Support Judgments', The Accounting Review 70(3), 467-488.

Poorsolton, K. S., G. Amin and A. Tootoonchi: 1991, 'Business Ethics: Views of Future Leaders', SAM Advanced Management Journal 56 (winter), 4-9.

Radtke, R. R.: 2000, 'The Effects of Gender and Setting on Accountants' Ethically Sensitive Decisions', Journal of Business Ethics 24(4), 299-312.

Rest, J.: 1986, Moral Development: Advances in Research and Theory, Praeger, NY.

Ruegger, D. and E. W. King: 1992, 'A Study of the Effect of Age and Gender upon Student Business Ethics', Journal of Business Ethics 11, 179-186.

Schminke, M. and M. L. Ambrose: 1997, 'Asymmetric Perceptions of Ethical Frameworks of Men and Women in Business and Nonbusiness Settings', Journal of Business Ethics 16, 719-729. 
Shaub, M. K., D. W. Finn and P. Munter: 1993, 'The Effects of Auditors' Ethical Orientation on Commitment and Ethical Sensitivity', Behavioral Research in Accounting 5, $145-169$.

Smith, A. and V. Rogers: 2000, 'Ethics-Related Responses to Specific Situation Vignettes: Evidence of Gender-Based Differences and Occupational Socialization', Journal of Business Ethics 28(1), 73-86.

Smith, P. L. and E. F. Oakley, III: 1997, 'Gender Related Differences in Ethical and Social Values of Business Students: Implications for Management', Journal of Business Ethics 16, 37-45.

Spurgin, E. W.: 2000, 'What's So Special about a Special Ethics for Business?', Journal of Business Ethics 24, 273-281.

Stanga, K. G. and R. A.Turpen: 1991, 'Ethical Judgments on Selected Accounting Issues: An Empirical Study', Journal of Business Ethics 10, 739-747.

Thorne, L.: 1998, 'The Role of Virtue in Auditors' Ethical Decision Making: An Integration of Cognitive-Developmental and Virtue-Ethics Perspectives', in L. A. Ponemon (ed.), Research on Accounting Ethics, Vol. 4, JAI Press Inc., CT, pp. 291-308.

Trevino, L.: 1992, 'Moral Reasoning and Business Ethics: Implications for Research, Education, and Management', Journal of Business Ethics 11, 445-459.

Trevino, L. K. and K. A. Nelson: 1995, Managing Business Ethics: Straight Talk About How To Do It Right, Wiley \& Sons, NY.

Tsalikis, J. and M. Ortiz-Buonafina: 1990, 'Ethical Beliefs' Differences of Males and Females', Journal of Business Ethics 9, 509-517.

Weber, J.: 1990, 'Managers' Moral Reasoning: Assessing Their Responses to Three Moral Dilemmas', Human Relations 43(7), 687-702.

Weeks, W. A., C. W. Moore, J. A. McKinney and J. G. Longenecker: 1999, 'The Effect of Gender and Career Stage on Ethical Judgment', Journal of Business Ethics 20, 301-313.

Wright, G. B., C. P. Cullinan and D. M. Bline: 1998, 'Recognizing Ethical Issues: The Joint Influence of Ethical Sensitivity and Moral Intensity', in L. A. Ponemon (ed.), Research on Accounting Ethics, Vol. 4, JAI Press Inc., CT, pp. 29-52.

Can Şımga-Mugan*

Bilkent University

Dept. of Management

06800 Bilkent, Ankara, Turkey

Tel: +90 312 290-1526

Fax: +90 312 266-4958

E-mail: simga@bilkent,edu.tr

* Research was carried out at SUNY at Buffalo

School of Business while the author was on sabbatical

(Author for correspondence)

Dilek Önkal-Atay

Bilkent University

Faculty of Bus. Admin.

06533 Bilkent

Ankara Turkey

Tel: +90 312 290-1596

Fax: +90 312 266-4958

E-mail: onkal@bilkent.edu.tr 
